Article

\title{
Environmental Aspects of Historical Ferromanganese Tailings in the Šibenik Bay, Croatia
}

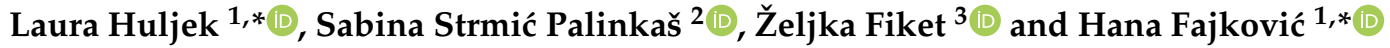 \\ 1 Department of Geology, Faculty of Science, University of Zagreb, Horvatovac 102B, 10000 Zagreb, Croatia \\ 2 Department of Geosciences, UiT-The Arctic University of Norway, Hansine Hansens veg 18, \\ 9019 Tromsø, Norway; sabina.s.palinkas@uit.no \\ 3 Division for Marine and Environmental Research, Ruđer Bošković Institute, Bijenička Cesta 54, \\ 10000 Zagreb, Croatia; zeljka.fiket@irb.hr \\ * Correspondence: laura.huljek@geol.pmf.hr (L.H.); hana.fajkovic@geol.pmf.hr (H.F.)
}

Citation: Huljek, L.; Strmić Palinkaš,

S.; Fiket, Ž.; Fajković, H.

Environmental Aspects of Historical

Ferromanganese Tailings in the

Šibenik Bay, Croatia. Water 2021, 13, 3123. https://doi.org/10.3390/ w13213123

Academic Editors:

Stanislav Frančišković-Bilinski and Sanja Sakan

Received: 14 October 2021

Accepted: 3 November 2021

Published: 5 November 2021

Publisher's Note: MDPI stays neutral with regard to jurisdictional claims in published maps and institutional affiliations.

Copyright: (C) 2021 by the authors. Licensee MDPI, Basel, Switzerland. This article is an open access article distributed under the terms and conditions of the Creative Commons Attribution (CC BY) license (https:// creativecommons.org/licenses/by/ $4.0 /)$.

\begin{abstract}
The former manganese ferroalloy plant and the remaining tailings are affecting the quality of the environment in Šibenik Bay, Croatia, even though industrial activities ceased more than 25 years ago. This study has revealed that the main manganese mineral phases present in the recently collected tailings, as well as in the dust collected on the roof of the plant during the production period, are bustamite and Mn-oxides. The same type of Mn mineral phases was also found in recently collected sediments from Šibenik Bay. Detailed chemical and phase analyses (XRD, BCR sequential analysis, aqua regia and lithium borate fusion) of the dust sample revealed high manganese values (24.1\%), while granulometric analysis showed that $50 \%$ of the particles are smaller than $\mathrm{PM}_{2.5}$. The influence of the tailings is visible in the sediment, but the concentrations of the potentially toxic elements determined by the sequential BCR analysis are within the legal limits. Some higher values $(20.3 \mathrm{~g} / \mathrm{kg} \mathrm{Mn}, 595 \mathrm{mg} / \mathrm{kg} \mathrm{Pb}$ and $494 \mathrm{mg} / \mathrm{kg} \mathrm{Zn})$ are detected in the tailings, which are still exposed to weathering and as such should be additionally monitored. On the other hand, this material contains a considerable number of elements that could be considered lucrative ( $\sum$ REE up to $700 \mathrm{mg} / \mathrm{kg}$, Mn up to $23 \mathrm{~g} / \mathrm{kg}$, Fe up to $37 \mathrm{~g} / \mathrm{kg}$ and $\mathrm{Al}$ up to $25 \mathrm{~g} / \mathrm{kg}$ ), opening the possibility of reuse and recovery.
\end{abstract}

Keywords: tailings; BCR sequential analysis; marine sediment; manganese; REE; recovery

\section{Introduction}

The negative impact of ferromanganese alloy production on the environment is well documented in the areas of historical and current facilities [1-5]. However, due to the increasing demand for manganese [6,7], such historical tailings may represent valuable secondary resources of manganese [8].

The quality of the environment in the town of Šibenik and the Šibenik Bay (Figure 1) has been affected by industrial activities since the establishment of the TEF plant (TEFTvornica elektroda i ferolegura; eng. Electrode and Ferroalloy Plant). The TEF plant was in production in the period between 1900 and 1995. The plant was producing calcium carbide from 1900 until 1945, when production of ferroalloys started, while in 1948 the plant activities were spread to manganese ferroalloy production as well. In 1998, the Croatian government decided to dismantle the plant and dispose of the waste [9]. However, the tailings still have not been fully remediated, and under the influence of strong winds, which can reach speeds up to $130 \mathrm{~km} / \mathrm{h}$ during windy seasons [10], tailing particles are transported over the wider Šibenik area including the nearby Krka River estuary (Figure 1).

Until the dismantling of the plant TEF, anthropogenically generated dust particles from the roof of the plant were transported by the aforementioned winds. In addition to the anthropogenic dust particles that were transferred, tailings particles are still being 
transferred. The negative impact of such particles on human health should not be neglected, as such fine particulate matter (PM) can cause severe damage [11-14].

The manganese ore mostly was delivered to the TEF plant from Greece, Turkey, Russia and India, but exact locations of the ore origin are not known. In the early years of production, energy-inefficient batch smelting technology was used, resulting in a low recovery rate and huge amounts of waste material [15]. After World War II, the processing technology at the TEF plant was modernised, and the recovery rate improved [15].

The main objective of this study is to determine the mineral and chemical composition of the historical tailings from the TEF plant to assess its impact on the quality of the marine sediments of Šibenik Bay and to evaluate its potential for manganese recovery.

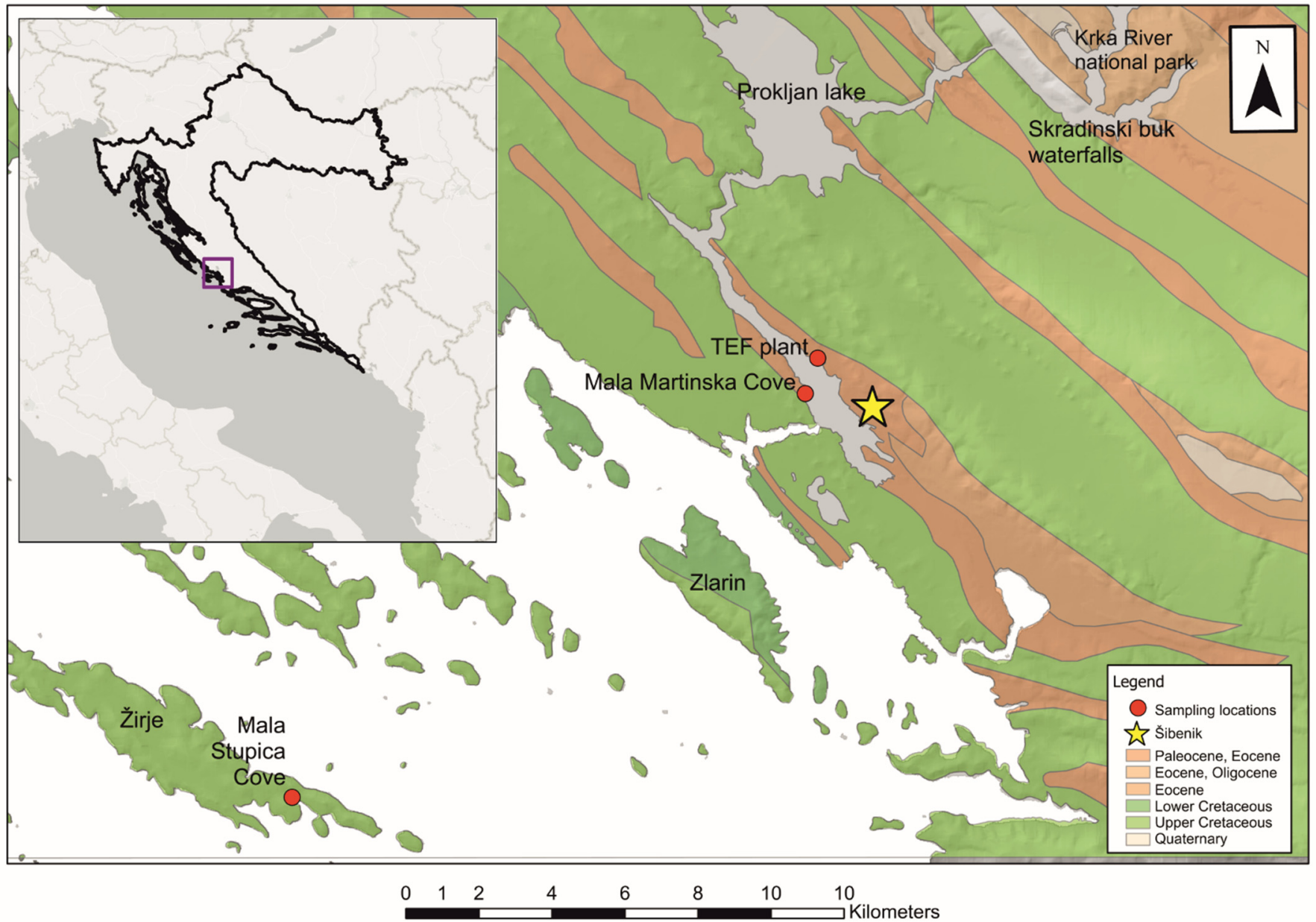

Figure 1. Geological map [16,17] of the study area with sampling locations marked (red dots) and the position of town of Šibenik (yellow star).

\section{Materials and Methods}

\subsection{Study Area and Environmental Conditions}

The Šibenik Bay is located on the eastern Adriatic coast (Figure 1). The Bay represents the lower part of the Krka River estuary, which lies downstream from the Krka National Park and Lake Prokljan. The Krka River is the main source of water supply for the citizens of Šibenik and the wider area [18].

The estuary begins below the Skradinski Buk waterfall in the north and ends at the St. Nicholas fortress in the south. The greatest depth is $22 \mathrm{~m}$. The area was formed in the Pleistocene and Holocene, when the Krka River and its tributaries Čikola and Guduća formed the canyons $[19,20]$. The estuary can be traced today to a depth of $60 \mathrm{~m}$ between the island of Zlarin and the mainland $[19,20]$. The bottom of the estuary consists of Upper 
Cretaceous carbonate deposits formed in shallow water. In some places, the contact between Upper Cretaceous and Palaeogene can be seen.

The estuary is divided into three well-separated layers: the lower seawater layer, the freshwater-saltwater interface layer and the fresh brackish water layer at the top. This observation is well explained in Cukrov [21]. As noted by Legović et al. [22], $\mathrm{O}_{2}$ concentrations near the waterfalls are lower near the bottom than in Lake Prokljan. To a lesser extent, hypoxia occurs off Šibenik [21,22]. As noted by Cukrov [21], the oxic zone in coastal sediments is often confined to the uppermost layer and reaches a thickness of a few millimetres or centimetres. Immediately below the oxic zone extends the 'suboxic' zone. This is the zone where denitrification processes take place and where $\mathrm{Mn} / \mathrm{Fe}$ oxyhydroxides are found. In this zone, Mn oxides and hydroxides are reduced, leading to an accumulation of dissolved $\mathrm{Mn}^{2+}$ in the pore water. Here, the $\mathrm{Mn}^{2+}$ species can be oxidised, precipitated as authigenic Mn oxyhydroxides and used in further diagenetic processes. Alternatively, $\mathrm{Mn}^{2+}$ can be stored in the anoxic sediments where its geochemical cycling is controlled by carbonate precipitation [21].

In estuaries, oxygen consumption is often greater than oxygen production, leading to hypoxia. In estuaries, hypoxia is the result of the high rate of decomposition of organic matter, which leads to stratification of the water column [22]. As noted in a previous study, the lower water layer in Šibenik Bay is colder and contains oxygenated water. This water originates from the surrounding sea. The bay is up to $40 \mathrm{~m}$ deep, and the lower part (about $30 \mathrm{~m}$ from the bottom) is unstratified [22].

Previous studies [23] have shown that the Krka River has the ability to self-purify $\mathrm{Pb}$, $\mathrm{Zn}$ and $\mathrm{Hg}$. The main reason for this behaviour is calcite and aluminosilicates, which are the main components of sediments. These compounds are considered to be the sink for most trace metals in the estuary. Studies from 1990 show that the concentrations of trace metals are higher in the upper parts of the estuary than in the lower part, which is Šibenik Bay [24].

Figure 1 shows two locations that were also of interest for this study. Mala Martinska Cove is located about $1 \mathrm{~km}$ from the TEF site and represents a place that is probably under the strong influence of the TEF site. Mala Stupica Cove is located outside Šibenik Bay on the island of Žirje and is approximately $19 \mathrm{~km}$ from the TEF site and was used as a reference site.

\subsection{Sampling}

Sampling was conducted in Šibenik Bay and included several types of samples: (1) a roof dust sample collected in the 1980s, (2) historical tailing samples collected in June 2020 and (3) marine sediments collected in June 2020 from Mala Martinska and Mala Stupica coves (Figure 1).

Sampling of tailings was done by hand collection and with a hand sampler. The first sample (TAILINGS) was taken from the top $5 \mathrm{~cm}$ of the tailings using a hand sampler: the sample consists of fragments up to $3 \mathrm{~cm}$ in size. The second sample (sample BTAILINGS) was taken from the surface of the pile with a hand collector. This sample contains only fragments larger than $3 \mathrm{~cm}$.

A dust sample collected from the roof of the TEF facility in the 1980s was also analysed (sample DUST).

Marine sediments from two sites (Mala Martinska Cove and Mala Stupica Cove, Figure 1) were sampled by a hand sampler. From the Mala Stupica Cove (sample MSTUP0-3) a composite sample of the uppermost $3 \mathrm{~cm}$ was collected, while in Mala Martinska two separated layers were sampled: a shallower layer at 0-3 cm depth (sample MMART0-3) and a deeper layer at 5-7 cm depth (sample MMART5). The MMART0-3 and MMART5 sediment samples contained fragments of beige to brown colour bigger than $1 \mathrm{~mm}$ in size, and samples had many fine-grained dark grey particles covering larger fragments. As sampling continues in the depth, the fine-grained cover disappears, and the sample is more beige and light brown in colour $(5-7 \mathrm{~cm})$. 


\subsection{Sample Preparation}

The sample TAILINGS has fragments of greyish-brownish colour, mostly with sharp edges. The sample was dried to constant weight. After drying, the sample was divided into four parts, and the other two parts were mixed. One half of the sample was homogenised in an agate mill and used for further analysis of the main samples, the other half was sieved for granulometric analysis, and the fractions obtained were used for further analysis. All samples, subsamples and sieved fractions were stored in plastic bags.

The samples of BTAILINGS material were dried to a constant weight after collection. These fragments can be divided into several subsamples based on their visual characteristics. Several different types of fragments were determined: loose fragments with many pores, usually beige with orange parts (sample TPORES); dark brown fragments, homogeneously coloured (sample TDBROWN); light brown fragments with parts of vitreous lustre (sample TCOMB); dark green vitreous fragments (sample GREEN GLASS); dark brown vitreous fragments (sample BEIGE GLASS) and dark grey, almost black fragments with metallic lustre (sample METALLIC LUTRE MATERIAL). All samples were stored in plastic bags.

The dust sample has a dark grey colour, with glittering fragments in beige colour. At the time of sampling, the dust sample was placed in an airtight container and stored in a dry place.

The marine sediment samples from Mala Martinska and Mala Stupica coves were dried to a constant weight at $102 \pm 2{ }^{\circ} \mathrm{C}$ after sampling. The samples were divided into four parts, and the opposite two parts were mixed. One half of the sample was homogenised using an agate mill and used for further bulk analyses. The other half of the samples were sieved for granulometric analysis. Different size fractions were then taken for further analysis.

\subsection{Grain Size Analysis}

Granulometric analysis of the sediment and tailings samples was carried out by dry sieving through sieves with mesh sizes of $4 \mathrm{~mm}, 2 \mathrm{~mm}, 1 \mathrm{~mm}, 0.5 \mathrm{~mm}, 0.250 \mathrm{~mm}, 0.125 \mathrm{~mm}$, $0.063 \mathrm{~mm}$. The samples were classified according to Folk [25] and the modified Wentworth scale [26], with the clay-silt boundary at $2 \mu \mathrm{m}$. The granulometric analysis of the dust sample was carried out using the Laser Diffraction Particle Size (LDS) Analyzer LS 13320 due to the small particle sizes. The granulometric compositions of the samples were calculated from the masses of the sieved fractions using GRADISTAT 9.1 software [27].

\subsection{SEM-EDS Pretreatment}

The dust sample was sieved through sieves with mesh size of $0.125 \mathrm{~mm}$ and $0.063 \mathrm{~mm}$, and the fraction $0.063-0.125 \mathrm{~mm}$ was used for separation of the heavy fraction. A heavy liquid sodium polytungstate (SPT) was used for the separation. The liquid was calibrated to a density of $2.915 \mathrm{~g} / \mathrm{cm}^{3}$. About $0.3 \mathrm{~g}$ of the dust sample was placed in a plastic cuvette, and $25-30 \mathrm{~mL}$ of SPT with the mentioned density was added. The contents of the cuvette were shaken and then placed in a centrifuge for $5 \mathrm{~min}$ at a speed of $2500 \mathrm{rpm}$. The cuvettes containing the separated fractions were placed in a freezer $\left(-18{ }^{\circ} \mathrm{C}\right)$ overnight. After freezing, the samples were carefully filtered with black band filter paper. After filtration, the samples were washed thoroughly with distilled water [28].

In addition, a sample from Mala Martinska Cove (5-7 cm depth; MMART5) was analysed using SEM-EDS (EDS-Oxford X-ACT) to relate the morphological characteristics of the dust particles to the chemical composition, i.e., to identify Mn-containing particles. The MMART5 sediment sample was treated with a 1:1 $\mathrm{HCl}$ solution to remove carbonates. The acidic solution was allowed to soak for $24 \mathrm{~h}$. The sample was then filtered and washed with distilled water, and $\mathrm{H}_{2} \mathrm{O}_{2}$ solution (1:1) was poured over it and allowed to react for $96 \mathrm{~h}$ to remove organic matter. Both the sediment samples and the light and heavy dust fractions were steamed with graphite prior to SEM-EDS analysis. 


\subsection{Analysis of Mineral Composition}

Qualitative X-ray powder diffraction analysis was carried out on Mala Martinska and Mala Stupica Cove sediments, tailings (and various subsamples of tailings), a dust bulk sample, sediment and tailing samples with a fraction size of $<0.063 \mathrm{~mm}$, undissolved BCR residues and each size fraction of Mala Martinska Cove sediments. The samples were ground in an agate mortar. Mineral composition was determined using a Philips X'pert powder diffractometer (Pananalitycal B.V. Einhoven, Netherlands) with $\mathrm{CuK} \alpha$ radiation from the tube at $40 \mathrm{kV}$ and $45 \mathrm{~mA}$, collecting X-ray diffraction dataset from $4^{\circ}$ to $63^{\circ} 2 \Theta$.

Heavy and light dust fractions were analysed using SEM-EDS JEOL JSM -35CF scanning microscope (EDS-Oxford X-ACT).

\subsection{Carbonate Content Analysis}

The carbonate content in the sediment was determined according to the Austrian standard method ÖNORM L 1084 using the Scheibler apparatus [29]. The carbonate content was determined on the bulk samples and the $<0.063 \mathrm{~mm}$ fraction of the sediment samples from Mala Martinska and Mala Stupica Cove, tailings and dust samples. The mass of the analysed samples was $\sim 300 \mathrm{mg}$. The carbonate content of Mala Stupica Cove was calculated according to Kostanjšek [30].

\subsection{BCR Sequential Analysis and Aqua Regia Control Analysis}

Chemical analyses were performed for dust, tailings and the sediment samples from Mala Martinska and Mala Stupica Cove sediment samples. First, a three-step BCR sequential analysis was performed with the additional step of aqua regia analysis (AR), then a control aqua regia analysis (AR) and finally, a total analysis using the lithium borate fusion.

The BCR sequential analysis and the total analysis were performed because of the different information they provide. The total analysis provides information about the chemical composition of the samples, while the sequential BCR analysis provides information about chemical elements bound to different phases. BCR stage 1 (BCR1) provides information about bioavailable elements that can be taken up by organisms and enter the food chain [31,32]. A control analysis AR was performed to control the BCR analysis, assuming that the measured concentrations should not differ significantly from the sum of the BCR steps. Both methods left a residual material that was not resolved in AR.

Sequential extraction analysis and control analysis AR were performed for the Mala Martinska Cove samples (MMART0-3, MMART5), Mala Stupica Cove sample (MSTUP0-3), tailings sample (TAILINGS) and dust sample (DUST) using the improved three-step BCR analysis with additional aqua regia step (AR) $[33,34]$ for the fraction $<0.063 \mathrm{~mm}$. The analysis for each sample was performed in duplicate using the BCR procedure and only once per sample for the control analysis AR. This AR analysis was performed using AR and following the instructions for the AR step of BCR analysis [33,34]. The mass of the samples used for the analysis was $\sim 500 \mathrm{mg}$ with the adjusted volumes. The acids used were of high purity (suprapur). The eluates were stored in plastic cuvettes.

The percentages of undissolved BCR and control AR residues were calculated by weighing the dried filter papers with residues. Before drying, the residues were washed in distilled water. The filter papers were weighed before filtration.

\subsection{Multielement Analysis by HR-ICP-MS}

Prior to analysis, all BCR extracts were diluted 100-fold, acidified with $2 \%(v / v) \mathrm{HNO}_{3}$ (65\%, Fluka, Steinheim, Switzerland) and In $\left(1 \mu \mathrm{gL}^{-1}\right)$ was added as an internal standard.

Multielement analysis of the prepared samples was performed by High Resolution Inductively Coupled Plasma Mass Spectrometry (HR-ICP-MS) using an Element 2 instrument (Thermo, Bremen, Germany). The typical instrument conditions and measurement parameters used throughout the work are reported in Fiket et al. [35]. 
All samples were analysed for the total concentration of 48 elements ( $\mathrm{Al}, \mathrm{As}, \mathrm{Ba}, \mathrm{Be}$, $\mathrm{Bi}, \mathrm{Ca}, \mathrm{Cd}, \mathrm{Ce}, \mathrm{Co}, \mathrm{Cr}, \mathrm{Cs}, \mathrm{Cu}, \mathrm{Dy}, \mathrm{Er}, \mathrm{Eu}, \mathrm{Fe}, \mathrm{Gd}, \mathrm{Ho}, \mathrm{K}, \mathrm{La}, \mathrm{Li}, \mathrm{Lu}, \mathrm{Mg}, \mathrm{Mn}, \mathrm{Mo}, \mathrm{Na}, \mathrm{Nd}$, $\mathrm{Ni}, \mathrm{P}, \mathrm{Pb}, \mathrm{Pr}, \mathrm{Rb}, \mathrm{S}, \mathrm{Sb}, \mathrm{Sc}, \mathrm{Se}, \mathrm{Sm}, \mathrm{Sn}, \mathrm{Sr}, \mathrm{Tb}, \mathrm{Ti}, \mathrm{Tl}, \mathrm{Tm}, \mathrm{U}, \mathrm{V}, \mathrm{Y}, \mathrm{Yb}$ and $\mathrm{Zn}$ ).

The quality control of the analytical procedure was carried out by the simultaneous analysis of the blank sample and the certified reference material for soil (NCS DC 77302, China National Analysis Center for Iron and Steel, Beijing, China). For all elements, good agreement was obtained between the analysed and certified concentrations within their analytical uncertainties $(\sim 10 \%)$.

\subsection{Total Analysis}

Total analysis was performed on dust, the $<0.063$-mm fraction of tailings and 3 subsamples of tailings: dark brown glassy fragments (BEIGE GLASS), dark green glassy fragments (GREEN GLASS) and dark grey fragments with metallic lustre (METALLIC LUSTRE MATERIAL). The subsamples were ground in an agate mill. Lithium borate fusion (LF100-EXT method) was used for analysis. The analysis was carried out at ACME Veritas Bureau in Canada.

\section{Results}

\subsection{Grain Size Distribution}

The grain size of the tailings was determined by entering the masses of the sieved fractions into the GRADISTAT software [27]. According to the grain size analysis (Figure 2a), the tailings are classified as muddy sandy gravel. The grain size of the dust sample was analysed using LDS and based on the particle size, it is silty sand in the sand-clay-silt diagram (Figure $2 \mathrm{~b}$ ). The dust size analysis shows that $90 \%$ of the dust particles have a diameter of less than $5.5 \mu \mathrm{m}$, of which $50 \%$ are smaller than $2 \mu \mathrm{m}$, i.e., they belong to the category $<\mathrm{PM}_{2.5}$. The granulometric analysis of the sediments of Mala Stupica Cove and Mala Martinska Cove classified all samples as sandy gravel.
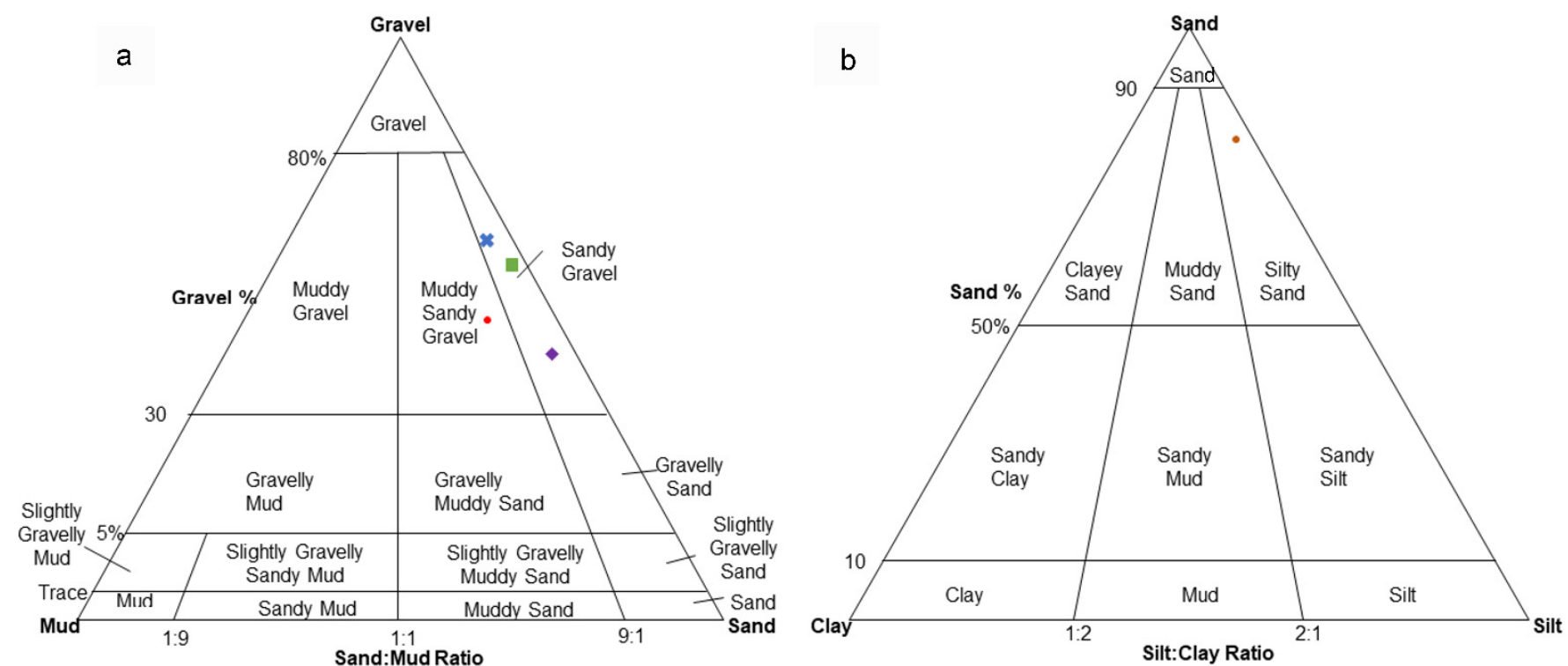

Figure 2. Granulometric composition of the samples: (a) shows gravel-mud-sand diagram in which are samples of the Mala Martinska Cove, MMART0-3 $(\times)$ and MMART5 ( $)$, Mala Stupica Cove, MSTUP0-3 ( $\square$ ) and tailings samples $(\bullet)$. In the sand-clay-silt diagram (b), only dust sample is shown $(\bullet)$.

\subsection{Mineral Composition}

The XRD data of the tailings $(<0.063 \mathrm{~mm})$ show calcite $\left(\mathrm{CaCO}_{3}\right)$, bustamite $((\mathrm{Ca}$, $\left.\mathrm{Mn})_{3} \mathrm{Si}_{3} \mathrm{O}_{9}\right)$, cristobalite $\left(\mathrm{SiO}_{2}\right)$, quartz $\left(\mathrm{SiO}_{2}\right)$ and manganese oxides $\left(\mathrm{MnO}_{\times} ;\right.$Figure 3$)$. 


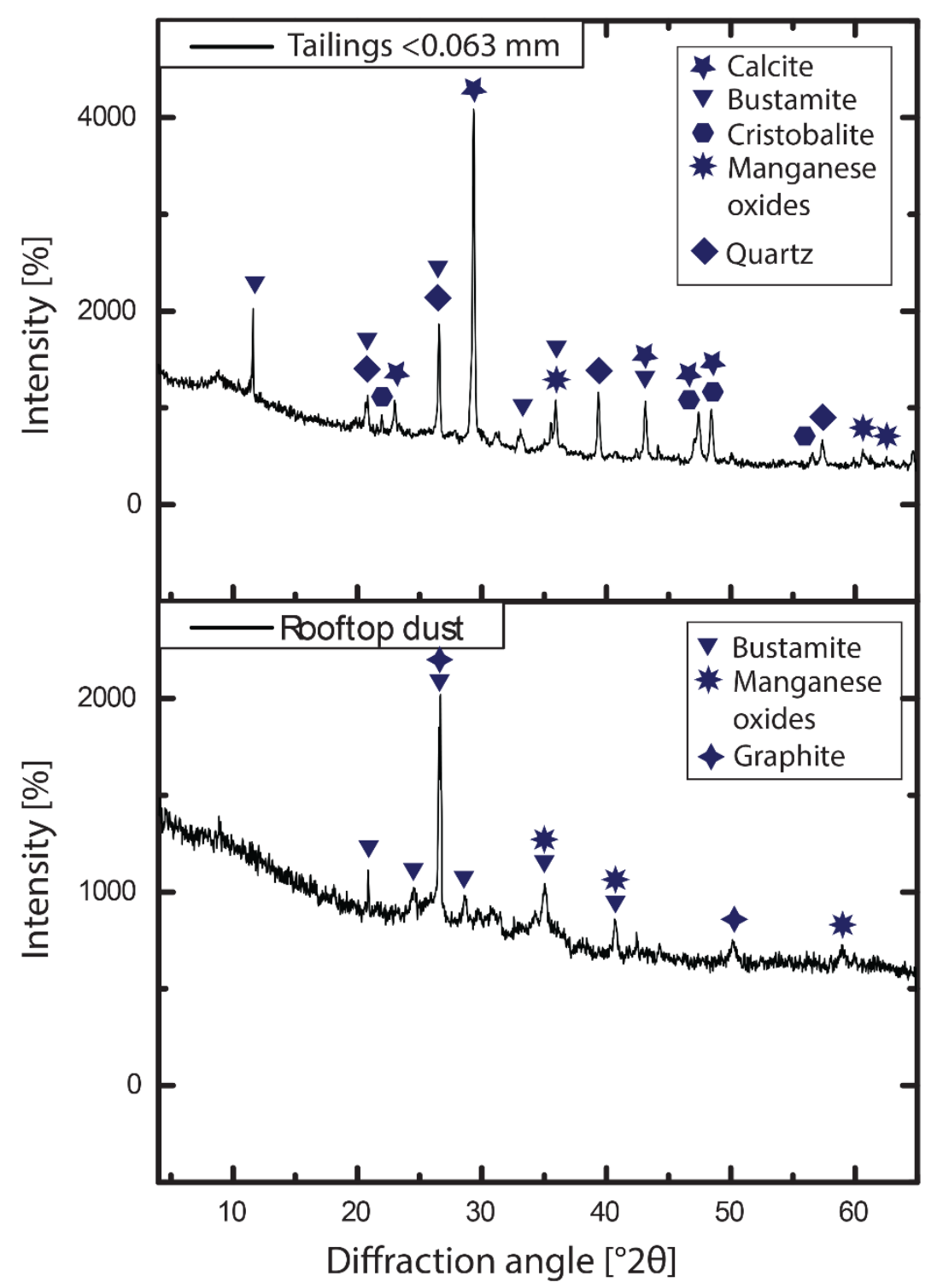

Figure 3. XRD data for tailings and dust sample.

After visual inspection of the tailings fragments larger than $3 \mathrm{~cm}$, different types of fragments were taken for XRD analysis. In general, the fragments can be divided into two main groups: one with an amorphous structure and a second with a crystalline structure. The second group usually contained some of the mineral phases mentioned above. A sample of SiMn material was also analysed and, as described in Jadrijević et al. [17], contained silicomanganese, but carbon was also determined. The above-explained materials, both types of glasses and the metallic lustre material, show an amorphous structure, and none of the phases could be identified by XRD.

The qualitative XRD data (Figure 3) of the dust sample of fraction $<0.063 \mathrm{~mm}$ show manganosite $(\mathrm{MnO})$, bustamite $\left((\mathrm{Ca}, \mathrm{Mn})_{3} \mathrm{Si}_{3} \mathrm{O}_{9}\right)$ and carbon as the constituents of a powder.

The qualitative XRD analysis shows calcite, aragonite, quartz and bustamite as phases in the MMART5 < $0.063 \mathrm{~mm}$ fraction and calcite, quartz and bustamite in the MMART0-3 $<0.063 \mathrm{~mm}$ fraction, respectively (Figure 4). In order to determine the distribution of $\mathrm{Mn}$ minerals through sediment fractions, in addition to the $<0.063 \mathrm{~mm}$ fraction, both MMART0-3 and MMART5 XRD analyses of granulometric fractions $>0.063 \mathrm{~mm},>0.125 \mathrm{~mm},>0.250 \mathrm{~mm}$, $>0.500 \mathrm{~mm},>1 \mathrm{~mm},>2 \mathrm{~mm}$ and $>4 \mathrm{~mm}$ were conducted. 


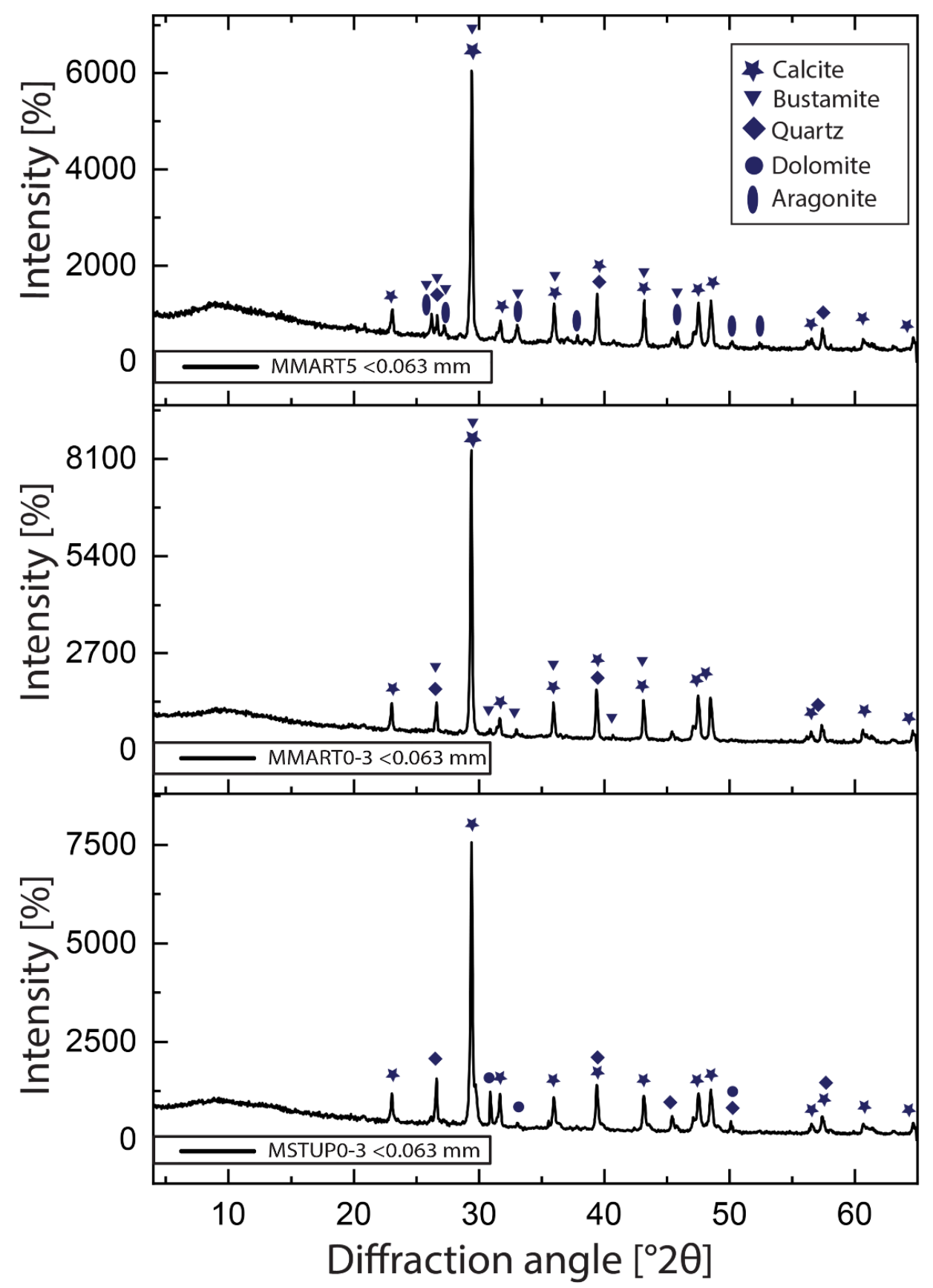

Figure 4. Mineralogical composition of sediments in Mala Stupica Cove and Mala Martinska Cove. Analysed fraction is $<0.063 \mathrm{~mm}$.

The results of XRD analysis show calcite, quartz and aragonite as the main mineral phases in all fractions and both samples. Besides the $<0.063 \mathrm{~mm}$ fraction, Mn phases were detected in the following fractions: $>0.063 \mathrm{~mm},>0.125 \mathrm{~mm},>0.250 \mathrm{~mm},>0.500 \mathrm{~mm},>1 \mathrm{~mm}$ and $>2 \mathrm{~mm}$. The only exception is the fraction $>4 \mathrm{~mm}$ in both MMART0-3 and MMART5, where no Mn phases were detected.

Qualitative XRD analysis shows the predominant mineralogical components to be: calcite, quartz and dolomite (Figure 4) in the sediment fraction $<0.063 \mathrm{~mm}$ of the Mala Stupica Cove.

XRD analysis of the undissolved residue in the tailings sample shows quartz and clay minerals after both analyses (BCR and control $\mathrm{AR}$ ), while the undissolved residue shows quartz and zircon as residues after BCR and only quartz after the control AR in the dust samples, respectively. XRD analysis of the undissolved residue after BCR and control AR 
analyses showed that all sediment residues (MMART0-3, MMART5, MSTUP0-3) consist of quartz and clay minerals, the same as the tailings sample.

The backscattered electron (BSE) images show three types of particles in the dust sample: spherical with smooth surfaces, irregularly shaped with sharp edges and rough surfaces and composite particles containing both spheres and sharp-edged fragments. All particles, regardless of their shape, contain $\mathrm{Mn}$. Nevertheless, the heavy and light dust fractions have some differences in particle composition. The heavy fraction contains only $\mathrm{Mn}, \mathrm{O}$ and $\mathrm{Si}$. There are exceptions, as can be seen in EDS spectra 5 (Figure 5), where $\mathrm{Ca}$, i.e., $\mathrm{Al}$ and $\mathrm{Mg}$ can be found. These elements are also seen in some EDS spectra in the heavy fraction but mostly in irregularly shaped fragments. The spherical particles are mainly composed of $\mathrm{Mn}, \mathrm{O}$ and $\mathrm{Si}$. On the other hand, the light fraction of the dust sample contains $\mathrm{Na}, \mathrm{K}$ and $\mathrm{Fe}$ in addition to $\mathrm{Mn}, \mathrm{O}, \mathrm{Si}, \mathrm{Ca}, \mathrm{Mg}$ and $\mathrm{Al}$ (Figures 5 and 6). A more complex composition is generally typical for the light dust fraction, as seen in Figures 5 and 6.
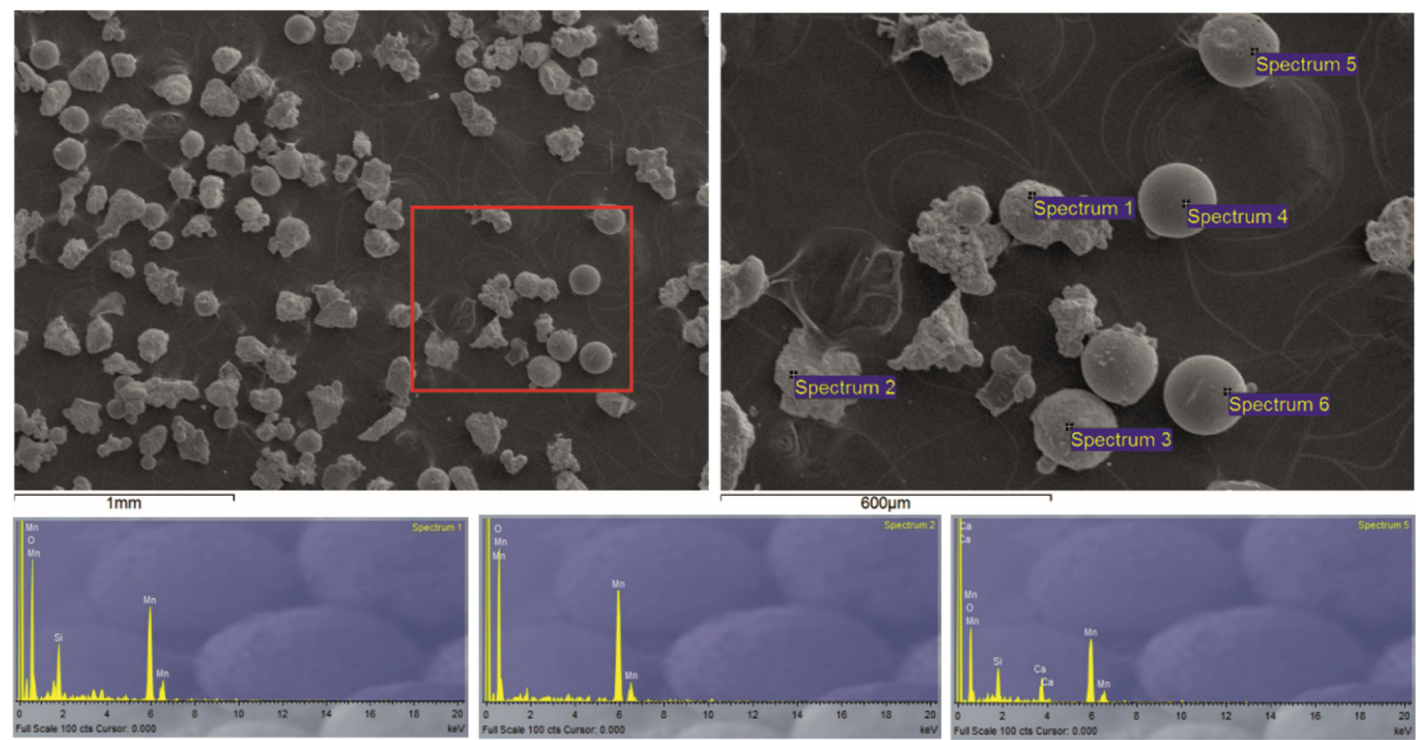

Figure 5. Backscattered electron images of the heavy dust fraction and EDS spectra of the selected grains.
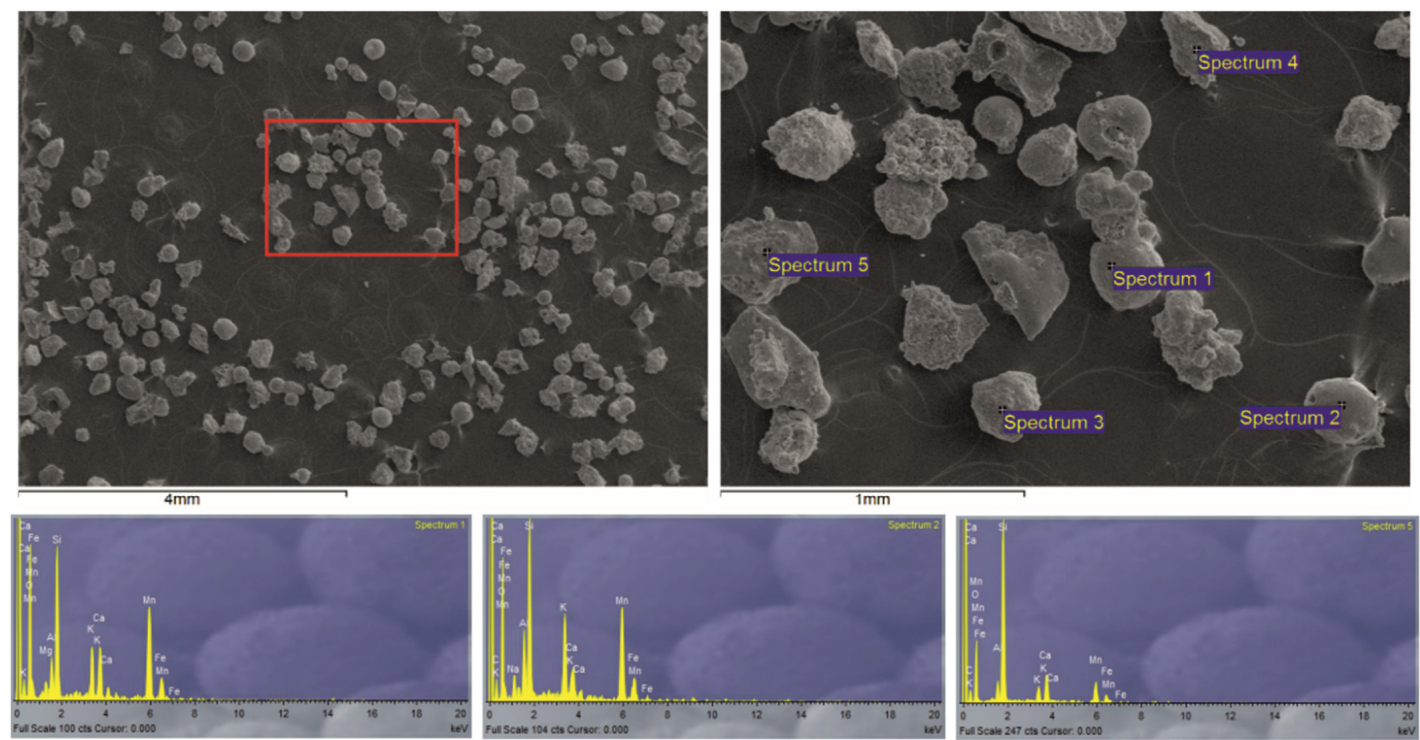

Figure 6. Backscattered electron images of the light dust fraction, and EDS spectra of the selected grains. 
The deeper layer of sediment from Mala Martinska Cove (MMART5 fraction 0.063-0.125 mm) was analysed using SEM-EDS. The analysis shows no spherical particles in the backscattered electron images. EDS spectra of the irregularly shaped fragments show $\mathrm{Si}$ and $\mathrm{O}$, with $\mathrm{K}, \mathrm{Fe}$ and $\mathrm{Al}$.

\subsection{Carbonate Share in Samples}

The results of the determination of carbonate content are shown in Table 1.

The tailings sample showed that the carbonate content in the fraction $<0.063 \mathrm{~mm}$ is higher $(40.7 \%$ carbonates) than in the tailings bulk sample (34.4\% carbonates; Table 1$)$. The higher carbonate content in the $<0.063 \mathrm{~mm}$ fraction could be explained by the fact that the bulk samples also contained larger fragments that include vitreous material and fragments with a metallic lustre and thus more amorphous and artificially derived products, which was not the case for $<0.063 \mathrm{~mm}$. The dust sample had a carbonate content of $7.72 \%$. Sediments from Mala Martinska Cove have a higher content of carbonate compared to dust and tailings (Table 1). In addition, the deeper layer (MMART5) contains 8\% higher carbonate content than the sample from the shallower layer (MMART0-3). The bulk samples also have 15\% (MMART0-3) and 26\% (MMART5) higher carbonate content than the fraction $<0.063 \mathrm{~mm}$. Mala Stupica Cove shows high carbonate content of $78.3 \%$ carbonates in the fraction $<0.063 \mathrm{~mm} \mathrm{[30].}$

Table 1. Content of carbonate components in the tailings, dust, Mala Martinska Cove sediment (depth 0-3 cm and 5-7 cm) and Mala Stupica Cove sediment samples in bulk and $<0.063 \mathrm{~mm}$ fraction.

\begin{tabular}{cc}
\hline Sample & Carbonate Content \\
\hline & $\%$ \\
\hline Tailings * & $34.4 \pm 0.9$ \\
\hline Tailings & $40.7 \pm 0.1$ \\
\hline Dust & $7.72 \pm 1.00$ \\
\hline MMART0-3 * & $77.9 \pm 0.9$ \\
\hline MMART0-3 & $66.0 \pm 1.0$ \\
\hline MMART5* & $94.5 \pm 2.3$ \\
\hline MMART5 & $71.4 \pm 0.02$ \\
\hline
\end{tabular}

\section{*Bulk samples.}

\subsection{BCR Sequential Analysis and AR Control Analysis}

The BCR sequential analysis provides information on the bioavailable elements after the first step has been performed, while the sums of the BCR steps indicate the semitotal concentrations of the elements of interest. Sequential BCR analysis of the tailings sample showed that Fe concentrations $(37 \mathrm{~g} / \mathrm{kg})$ are higher than manganese concentrations (23 g/kg; Table S1) when BCR steps are summed ( $\Sigma B C R)$. Iron is most abundant in the residual fraction ( $34 \mathrm{~g} / \mathrm{kg}$ ), while $\mathrm{Mn}$ is present in the reducible fraction (17 g/ kg; Figure 7). Aluminium, $\mathrm{P}, \mathrm{Pb}$ and $\mathrm{Zn}$ are also abundant in the tailings (Tables S2 and S3). The sum of REE ( $\Sigma R E E$ ) in the BCR steps in the tailings is $108 \mathrm{mg} / \mathrm{kg}$, and the control analysis AR shows a difference of $16 \%$ in the $\Sigma B C R$ steps. From the graphs in Figure 7 , it can be seen that most of REE is contained in oxidisable and residual fractions. 

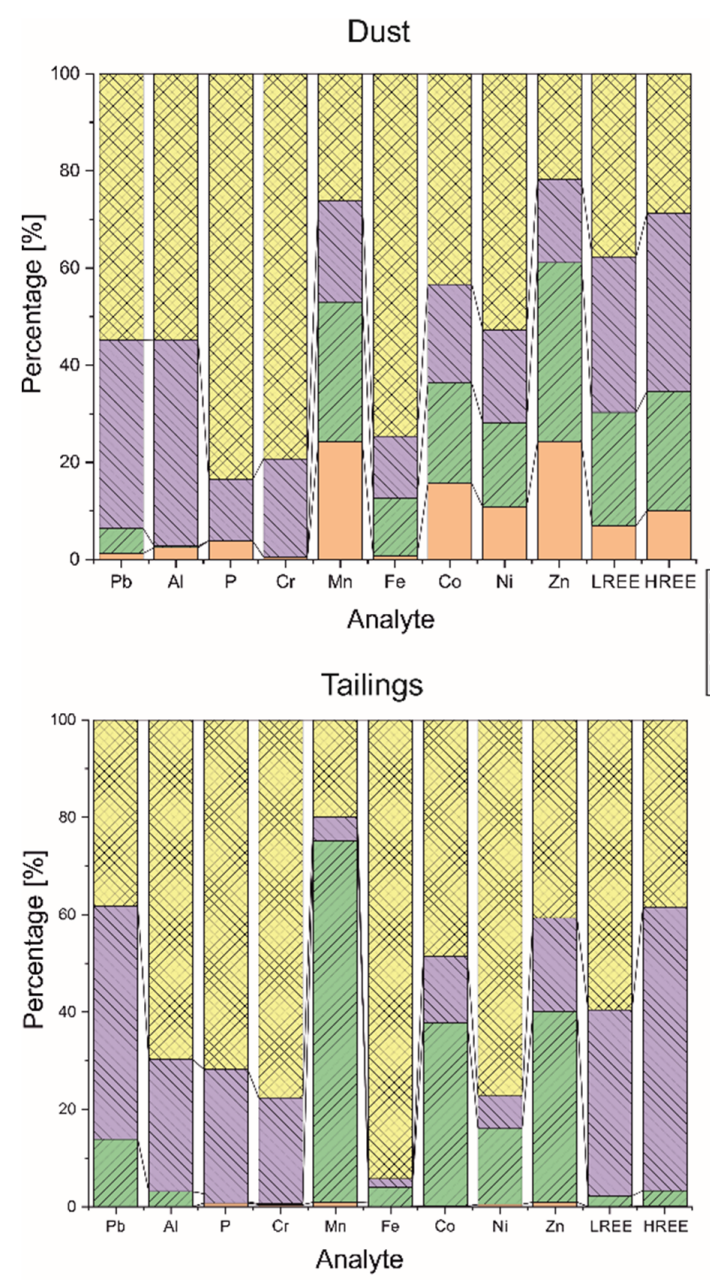

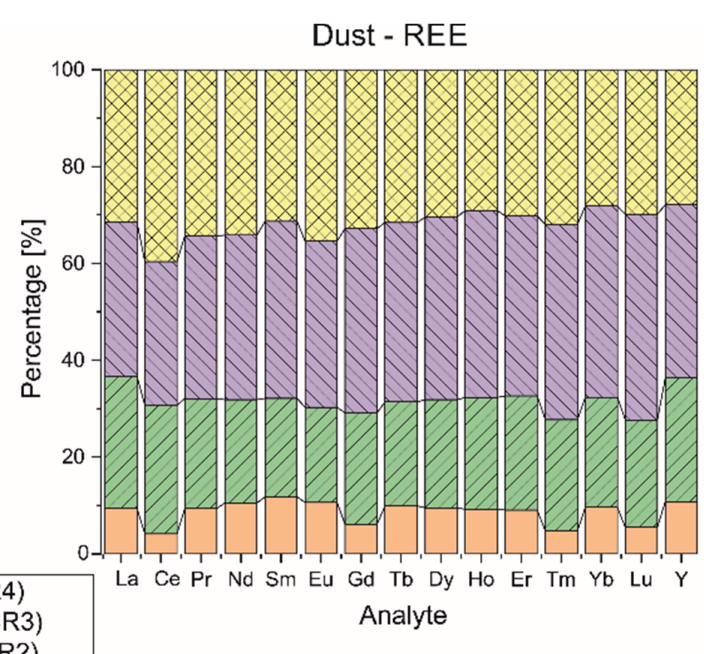

Tailings - REE

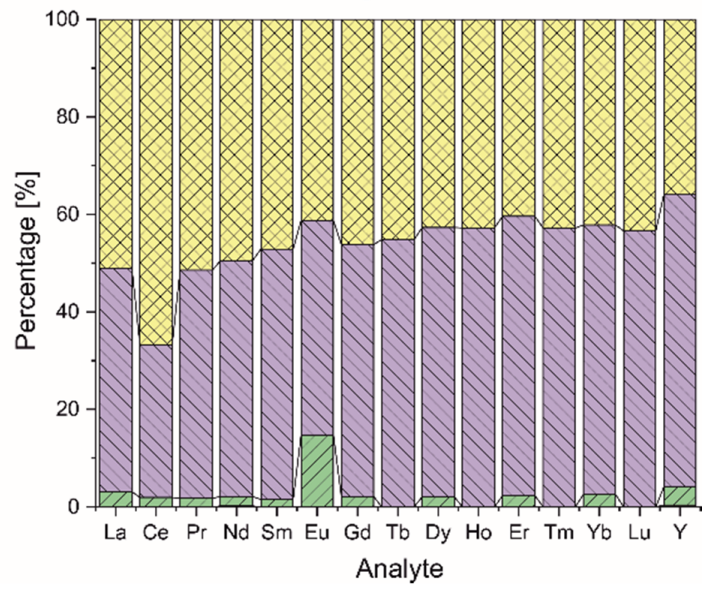

Figure 7. Weight fraction of analysed elements in dust and tailings obtained by BCR sequential analysis. Y is added to HREE due to its chemical and physical affiliations as stated in [36].

Manganese values in dust exceed $256 \mathrm{~g} / \mathrm{kg}$ when BCR steps are summed (Table S1), with the highest values found in the reducible fraction (Figure 7). The control AR analysis shows a difference of $\pm 12 \%$ compared to the BCR analysis. It can be seen that most of the $\mathrm{Mn}$ is bound in the reducible fraction, which represents elements bound to iron and manganese oxyhydroxides [37]. Iron has lower values in the dust above $46 \mathrm{~g} / \mathrm{kg}$, with the highest value found in the residual fraction. $\Sigma$ REE exhibits concentrations of $\approx 100 \mathrm{mg} / \mathrm{kg}$, with LREE having a higher concentration $(87 \mathrm{mg} / \mathrm{kg})$ than HREE $(8.40 \mathrm{mg} / \mathrm{kg})$, corresponding to $\Sigma B C R$ values for each step. Cerium has the highest measured concentrations $(\approx 30 \mathrm{mg} / \mathrm{kg}$ ), with the highest abundance in the residual fraction (Figure 7). Lanthanum, $\mathrm{Y}$ and Nd are present at concentrations of about $15 \mathrm{mg} / \mathrm{kg}$ each (Tables S3 and S4). The only other metal with values above $1 \mathrm{~g} / \mathrm{kg}$ is $\mathrm{Zn}(2.4 \mathrm{~g} / \mathrm{kg})$ when BCR steps are summed. Table $\mathrm{S} 2$ shows that in addition to the above metals, there is enrichment of $\mathrm{Pb}$ and $\mathrm{P}$ compared to background levels from Mala Stupica Cove.

The undissolved BCR residue is $37 \%$ in the dust and $36 \%$ in the tailings sample, while in the control AR analysis in the dust and tailings sample, the undissolved residue is about $60 \%$ and $55 \%$ of the initial weight, respectively.

The top layer from Mala Martinska Cove (MMART0-3) shows Mn values of $500 \mathrm{mg} / \mathrm{kg}$, and the control AR shows values $8 \%$ lower than the $\Sigma$ BCR levels (Table S1). The results of the $\Sigma B C R$ stages from the MMART5 site show about $1.4 \mathrm{~g} / \mathrm{kg}$ of Mn, while the value for the AR control is $13 \%$ higher (Table S1). Most of the $\mathrm{Mn}$ is in an oxidisable fraction, as seen in Table S1; Fe also has concentrations above $14 \mathrm{~g} / \mathrm{kg}$ at 0-3 depth (MMART0-3) and $22 \mathrm{~g} / \mathrm{kg}$ in the layer at $5 \mathrm{~cm}$ depth (MMART5). All other metals mentioned have concentra- 
tions below $500 \mathrm{mg} / \mathrm{kg}$ (Tables S1-S7). The $\Sigma$ REEs in the sediments have concentrations $<50 \mathrm{mg} / \mathrm{kg}$ (45 mg/kg in MMART0-3 and $28 \mathrm{mg} / \mathrm{kg}$ in MMART5), with Ce having the highest values (Tables S3-S7). The REEs are mostly bound to an oxidisable fraction. The residual undissolved material after BCR and AR analyses is $20 \%$ and $42 \%$ (MMART0-3) and $11 \%$ and $37 \%$ (MMART5), respectively.

Sequential BCR analysis of sediments in Mala Stupica Cove sediments (Tables S1-S7) shows Fe values greater than $3 \mathrm{~g} / \mathrm{kg}$ (Table S1). These concentrations are related to all three steps of BCR analysis: reducible, oxidisable and residual fraction, with the highest value at $3 \mathrm{~g} / \mathrm{kg}$ in the residual fraction. All other elements of interest as well as REE show concentrations below $100 \mathrm{mg} / \mathrm{kg}$.

\subsection{Total Analysis}

Total analysis of the two types of vitreous material and material with a metallic lustre (METALLIC LUSTRE MATERIAL) showed that the dark brown vitreous fragments (BEIGE GLASS) have elevated concentrations of $\Sigma$ REE ( $\approx 550 \mathrm{mg} / \mathrm{kg}$ ), Zr, W, U, Th, Ta, Hf, Be and more (Table S8) when compared to Mala Stupica Cove sediments BCR and control AR data. However, green glass contains even higher concentrations of $\Sigma R E E(\approx 750 \mathrm{mg} / \mathrm{kg}), \mathrm{Zr}, \mathrm{U}$, $\mathrm{Th}, \mathrm{Sr}, \mathrm{Rb}, \mathrm{Hf}, \mathrm{Se}, \mathrm{Ni}$ and $\mathrm{Cu}$ than beige glass. The third type of tailings-fragments with a metallic lustre-have lower values of $\Sigma$ REE $(\approx 4 \mathrm{mg} / \mathrm{kg})$ when compared to previously mentioned tailings subsamples and values of $\mathrm{Zr}, \mathrm{W}$, Sr, Ba, Se, $\mathrm{Hg}$, Sb, As, $\mathrm{Ni}, \mathrm{Zn}, \mathrm{Pb}, \mathrm{Cu}$ and Mo below $15 \mathrm{mg} / \mathrm{kg}$.

\section{Discussion}

\subsection{Impact of the TEF Plant on the Environment}

In order to evaluate the impact of industrial production of ferromanganese alloys on sediment in Šibenik Bay, a comparison of sediments from two locations was carried out. Mala Stupica Cove was determined as the site with the background values due to its location-a beach $19 \mathrm{~km}$ away in the outer archipelago of Šibenik. The Mn values in Mala Stupica Cove reach $43 \mathrm{mg} / \mathrm{kg}$ using only AR, while the $\Sigma B C R$ level amounts to $29 \mathrm{mg} / \mathrm{kg}$. These values are low but indicate the potential dust exposure from the Šibenik plant. It can be seen (Table S1) that the Mn content in the dust sample is high: $25.6 \%$ in the $\Sigma \mathrm{BCR}$ steps and $24 \%$ in the AR analysis. Nevertheless, the sediments of Mala Stupica Bay are to be classified as background due to the low values of the metals of interest.

The XRD sediment analysis of both locations, Mala Martinska and Mala Stupica Cove, shows calcite, dolomite and quartz as the main mineral phases, which is in accordance with the previous analysis of Cukrov [21]. The content of carbonate components is high-over $65 \%$ in MMART0-3, which is the lowest measured value in all sediment samples (Table 1), confirming the results of XRD data. Since the eastern Adriatic coast is predominantly composed of limestone, such sediment composition is typical $[20,38]$. In addition to the already mentioned mineral phases, bustamite was also determined in the sediment samples of Mala Martinska Cove, as mentioned in Bilinski et al. [39].

The $\mathrm{Mn}$ and Fe values in the sediment samples from Mala Martinska Cove show significant enrichment compared to the values from Mala Stupica Cove. The detected Mn values are $\approx 500 \mathrm{mg} / \mathrm{kg}$, AR analysis shows $8 \%$ lower values $(462 \mathrm{mg} / \mathrm{kg})$ in the sample MMART0-3, while the Mn values in the sample MMART5 are $\approx 1400 \mathrm{mg} / \mathrm{kg}$ for the values of $\Sigma B C R$ steps and $\approx 1600 \mathrm{mg} / \mathrm{kg}$ for the control AR analysis. These data confirm the strong influence of the TEF plant on the sediments in the surrounding area.

The $\Sigma$ REE values in the Mala Martinska Cove samples also show higher values than in the Mala Stupica Cove samples. In the uppermost layer, $\Sigma$ REE values are $45 \mathrm{mg} / \mathrm{kg}$, while in the sediment layer at 5-7 cm depth, $\Sigma R E E$ values are $28 \mathrm{mg} / \mathrm{kg}$. In both samples, Ce has the highest values (Table S4). The highest Ce content could be due to the Ce anomaly and the fact that Ce can substitute for Mn in the marine environment [40]. This is also supported by the positive correlation of the highest values of manganese in the oxidisable fraction 
with the highest values of Ce. This trend is evident in both MMART0-3 and MMART5, while it is absent in MSTUP0-3 due to low Mn concentrations.

Due to numerous environmental problems, governments tend to issue strict guidelines prescribing the permissible concentrations of elements in various environmental components (water, soil, sediment, air, etc. [41-43]). European Union (EU) regulations state that sediment and water are interconnected [41], but the authors are not aware of any strictly established limits for elements of interest in this research on sediments so far. Since the studied area is located in Croatia and is subject to EU legislation, Croatian legislation is in line with EU legislation. On the other hand, there are some examples of precisely defined limit values. All the mentioned regulations and limits are based on the overall analysis of the samples. Although the BCR sequential analysis was classified as semi-total analysis due to the undissolved residue, the sum of BCR steps can be used as total values of metal concentrations for comparison with regulations. In sum, the BCR1 step for the sediments of Mala Stupica Cove proves that none of the values of $\mathrm{As}, \mathrm{Co}, \mathrm{Cr}, \mathrm{Cu}, \mathrm{Pb}, \mathrm{Ni}$ and $\mathrm{Zn}$ exceed the limits prescribed in the mentioned legislation and previous studies [43-45]. This is further evidence that Mala Stupica can be used as background levels. The $\Sigma B C R$ levels for the Mala Martinska Cove sediments exceed the prescribed values. However, it is known that the first BCR level represents the bioavailable concentrations of elements [31,32], so more attention was paid to these concentrations (BCR1) compared to the threshold values.

Bakke et al. [44] compared the measured values in the samples with the background values for certain metals in Norway. Figure 8 shows that only $\mathrm{Cd}$ in the tailings in the BCR1 step exceeds the Norwegian background values (NBV), but the BCR1 values in the sediments from Mala Martinska and Mala Stupica Coves are still below the NBV.
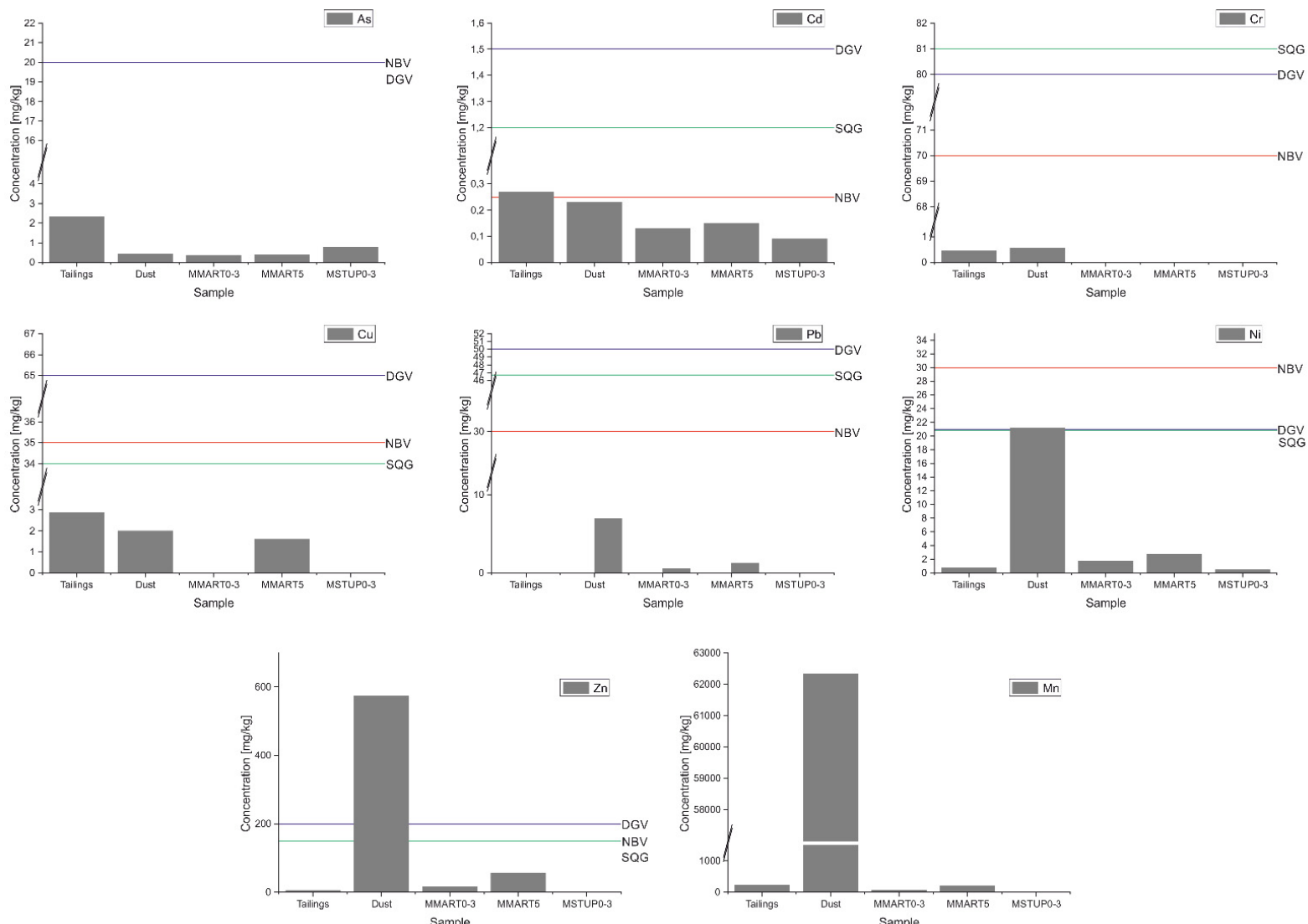

Figure 8. Measured values of the metals in sediment in the first step of BCR sequential analysis (exchangeable fraction) compared to threshold limit values in legislation. NBV-Norway background values [44], DGV—default guideline values [43], SQG—sediment quality guidelines [45]. 
Australian legislation has slightly different thresholds. It can be seen that $\mathrm{Zn}$ in the BCR1 of the dust sample exceeds the Australian government standard guidance values (DGV—default guideline values) [43] and Zn exceeds both the NBV values [44] and the SQG (sediment quality guidelines) values provided by Pejman et al. [45]. The Zn concentrations in the sediment samples are below all the above thresholds. This indicates that either the high concentration that entered the sediment was very dilute, showing the ability of the estuary (Šibenik Bay) to self-purify, as explained by Cukrov et al. [46], or the concentration that entered the sediment was low. However, since self-purification was found in Šibenik Bay and in the entire Krka River estuary, the first of the two conclusions is more likely. This ability of self-purification was demonstrated for $\mathrm{Zn}, \mathrm{Cu}, \mathrm{Pb}$ and $\mathrm{Cd}$ [46].

In addition to $\mathrm{Cd}$ and $\mathrm{Zn}, \mathrm{Ni}$ in the dust sample also exceeds the threshold values, DGV and SQG, provided by the Australian government [43] and Pejman et al. [45], respectively. Again, it can be seen that the concentrations in the sediment are much lower than the threshold values.

It is worth noting that these regulations and studies do not include manganese in their list of toxic metals, although it is known that $\mathrm{Mn}$ is toxic to all organisms at high concentrations. As noted by Hernroth et al. [47], Mn becomes bioavailable through eutrophication, which leads to reductive conditions and can remain bioavailable for long periods of time. When exposed to elevated Mn concentrations, certain changes occur in the immune parameters of aquatic organisms. Previous studies have shown that exposure to $\mathrm{Mn}$ concentrations of $3.9 \mathrm{mg} / 1$ in water for 4 days leads to significant changes in the immune parameters of organisms. Since the $\Sigma B C R$ values of $\mathrm{Mn}$ in the sediment samples from Mala Martinska Cove are $462 \mathrm{mg} / \mathrm{kg} \pm 7.8 \%$ in the shallower layer and $1.60 \mathrm{~g} / \mathrm{kg} \pm 12.8 \%$ in the deeper layer, respectively, and hypoxia occurs regularly but to a lesser extent in this area [22], it is expected that $\mathrm{Mn}$ is bioavailable to organisms in the water of Šibenik Bay, causing changes in their functioning. The bioavailable concentrations of $\mathrm{Mn}$, i.e., BCR1 from the shallower layer are $65 \mathrm{mg} / \mathrm{kg}$ and $211 \mathrm{mg} / \mathrm{kg}$ from the deeper layer. These concentrations cause acute conditions in some organisms (sponges) and are much higher than the levels found in the study of the effects of Mn on starfish, molluscs, crustaceans and fish [47]. Manganese is abundant in coastal and deep-sea sediments [47] in general, and not only in the Šibenik Bay area, and should therefore be included in the sediment legislation.

When considering the transmission of tailings particles by wind, the adverse effects of such particles on human health should not be neglected. It is well known that particulate matter (PM) is a major threat to human health, with $\mathrm{PM}_{2.5}$ being the most dangerous and penetrating deep into the lungs [11-13]. The analysis by Kero et al. [14] showed that $\mathrm{PM}_{2.5}$ can reach a distance of $25 \mathrm{~km}$ in a year and cause health and environmental problems. The granulometric analysis of the dust sample showed that $50 \%$ of the particles are $<2 \mu \mathrm{m}$ in size, indicating the harmful effects of dust from the roof of the plant TEF. Nowadays, PMs are carefully monitored [48,49].

\subsection{Tailings as Potential Recovery Material}

The Mn concentrations in the tailings are about $2 \% \mathrm{Mn}$ (Table S1). These values are somewhat lower than those required for cost-effective recovery [50,51]. Nevertheless, the increasing demand for $\mathrm{Mn}$ may make these tailings attractive for reprocessing in the near future [52].

The literature suggests that only a small percent of REE in tailings can be considered sufficient for recovery. Nevertheless, new approaches and technologies should be considered in the recovery of REE [53]. Concentrations of REE in tailings samples exceed values of $\approx 100 \mathrm{mg} / \mathrm{kg}$ in BCR analysis and $90 \mathrm{mg} / \mathrm{kg}$ in AR analysis. When different subsamples of the tailings were analysed using the total analysis, the glasses were found to contain $403 \mathrm{mg} / \mathrm{kg}$ REE and $540 \mathrm{mg} / \mathrm{kg}$ REE for beige glass and green glass, respectively. These contents are quite high considering that deposits with much lower concentrations are currently being investigated [54]. Literature [55] indicates that some tailings contain 
$413 \mathrm{mg} / \mathrm{kg}$ REE. Although these tailings are phosphogypsum, these amounts measured in the Šibenik Bay tailings could be sufficient with appropriate concentration and separation methods.

\subsection{Tailings and Dust Characteristics}

According to the XRD data, the mineral phases identified in the tailings analysed in this study were also present in different types of tailings in previous studies [39]. These include bustamite, graphite, manganese oxides, calcite and quartz. In addition, one of the subsamples of the tailings had the mineralogical composition of silicomanganese as described in Jadrijević et al. [56].

XRD analysis of the undissolved residues shows mineral phases that were not detected in the bulk or $<0.063 \mathrm{~mm}$ fraction. This indicates that these mineral phases are present at lower concentrations and became visible in the XRD data after dissolution of the major constituents.

As shown in the Results section, the dust sample contains three types of particles, all containing Mn. The literature [57,58] confirms the morphological characteristics of the dust particles identified in the backscatter images. The morphologies detected in the dust sample particles are characteristic of industrial processes, and the process of formation of industrial dust particles is explained in the literature using fly ash particles as an example [58]. The data from SEM-EDS are in agreement with the XRD data (Figures 3, 5 and 6). It can also be seen that the spherical particles are mainly composed of $\mathrm{Mn}, \mathrm{O}$ and $\mathrm{Si}$, which is consistent with the findings in the literature [57]. It was assumed that some of these particles are also present in the MMART5 sample, since the MMART5 sample has higher Mn values than the MMART0-3 sample, and the sedimentation rates [59] of the area determine the depth of the sediment sample $(5-7 \mathrm{~cm})$ at the time of dust sampling. The backscatter images showed no dust particles in the MMART5 sample, and the EDS spectra showed no Mn in the sample. The explanation for this lies in the fact that the MMART5 sample was treated with $\mathrm{HCl}$ to facilitate the identification of the dust particles. Subsequently, the sample was treated with $\mathrm{H}_{2} \mathrm{O}_{2}$. As BCR analysis showed, the highest Mn concentrations in the MMART5 sample were bound to an oxidisable fraction treated with $\mathrm{H}_{2} \mathrm{O}_{2}$. This is probably the reason why no dust particles were detected in the SEM-EDS spectra of the MMART5 sample.

As mentioned in the literature [21] and earlier in the text, the TEF plant can be a source of many elements such as $\mathrm{Pb}, \mathrm{Al}, \mathrm{Cr}, \mathrm{Fe}, \mathrm{Ni}, \mathrm{Co}, \mathrm{Zn}$, etc. Phosphorus is also one of these elements. It was assumed that phosphorus comes only from the transport and transshipment of phosphate ore [19], which is one of the main tasks in the port of Šibenik. Although it is known that during reloading, a certain amount was lost in the river mouth, it can be seen that the tailings also contain a certain amount of P (Figure 7 and Table S2). In addition, phosphorus in the samples from Mala Martinska Bay is mainly bound to the residual fraction. From all these data, it can be concluded that the measured amounts of $\mathrm{P}$ could partly originate from the handling of phosphate ore in the port of Sibenik. However, such high levels of $\mathrm{P}$ in a residual fraction of tailings and dust samples suggest that the phosphorus in the sediments also originates from the TEF plant. This claim is also supported by the fact that phosphate ore is usually dissolved in the first two steps of the BCR sequential analysis, which was not the case in this study [60].

\section{Conclusions}

A large amount of the tailings material is still present at the site of the historic facility. Multiapproach analyses of the sediment near the TEF plant (Mala Martinska Cove) confirmed that the area of Šibenik Bay was under the strong influence of the TEF plant and is probably still under the influence of its by-products today. The present influence can be explained by the transport of tailings material by wind and sea.

Chemical analyses revealed up to $20 \mathrm{~g} / \mathrm{kg}$ Mn and $700 \mathrm{mg} / \mathrm{kg} \Sigma \mathrm{REE}$ in some of the subsamples of the tailings, which defines them as potential material for recovery. Manganese also has high concentrations in the sediments. However, there are no regulations for its 
levels, making it a potentially hazardous uncontrolled parameter in the environment. In contrast, the concentrations of $\mathrm{Zn}, \mathrm{Cd}$ and $\mathrm{Ni}$ in the dust sample exceed the prescribed levels, although the concentrations measured in the sediments are much lower.

Following all the above, further analyses are needed to determine the range of manganese ore by-products and tailings in Šibenik Bay. It is also necessary to understand how the conditions in the deposited tailings change with depth in order to understand the behaviour in the deeper parts of the tailings hill and the real threat they pose to the environment and the Krka River estuary as a sensitive and easily changing environment.

Supplementary Materials: The following are available online at https: / www.mdpi.com/article/ 10.3390/w13213123/s1, Table S1: Concentrations of the Mn, Fe, Co and Ni (expressed in mg/kg) in BCR fractions and AR eluates of the tailings sample. Table S2: Concentrations of the Pb, Al, P and $\mathrm{Cr}$ (expressed in $\mathrm{mg} / \mathrm{kg}$ ) in BCR fractions and AR eluates of the tailings sample. Table S3: Concentrations of the $\mathrm{Cu}, \mathrm{Zn}$, Sc and $\mathrm{Y}$ (expressed in $\mathrm{mg} / \mathrm{kg}$ ) in BCR fractions and AR eluates of the tailings sample. Table S4: Concentrations of the $\mathrm{La}, \mathrm{Ce}, \mathrm{Pr}$ and $\mathrm{Nd}$ (expressed in $\mathrm{mg} / \mathrm{kg}$ ) in BCR fractions and AR eluates of the tailings sample. Table S5, Concentrations of the Sm, Eu, Gd and $\mathrm{Tb}$ (expressed in $\mathrm{mg} / \mathrm{kg}$ ) in BCR fractions and AR eluates of the tailings sample. Table S6: Concentrations of the Dy, Ho, Er and Tm (expressed in $\mathrm{mg} / \mathrm{kg}$ ) in BCR fractions and AR eluates of the tailings sample. Table S7: Concentrations of the $\mathrm{Yb}$, Lu and $\Sigma \mathrm{REE}$ (expressed in $\mathrm{mg} / \mathrm{kg}$ ) in BCR fractions and AR eluates of the tailings sample. Table S8: Concentrations of different elements provided by total analysis using lithium borate fusion. Data are given in $\mathrm{mg} / \mathrm{kg}$.

Author Contributions: Conceptualisation, L.H. and H.F.; Methodology, L.H., H.F. and S.S.P.; Software, L.H.; Validation, L.H., Ž.F., S.S.P. and H.F.; Formal Analysis, L.H.; Investigation, L.H.; Resources, L.H., H.F. and Ž.F.; Data Curation, H.F., S.S.P., Ž.F. and L.H.; Writing-Original Draft Preparation, L.H.; Writing-Review and Editing, H.F, Ž.F. and S.S.P.; Visualisation, L.H.; Supervision, H.F. and S.S.P.; Project Administration, H.F.; Funding Acquisition, S.S.P., H.F. and Ž.F. All authors have read and agreed to the published version of the manuscript.

Funding: This research received no external funding.

Institutional Review Board Statement: Not applicable.

Informed Consent Statement: Not applicable.

Data Availability Statement: Data are contained within the article or Supplementary Materials.

Acknowledgments: This work has been supported in part (samples collection) by the Croatian Science Foundation under the project IP-2019-04-5832. The authors thank the Croatian Geological Survey for allowing the work on the SEM-EDS scanning microscope. Authors thank Željko Kwokal for providing the dust sample for the analysis.

Conflicts of Interest: The authors declare no conflict of interest. The funders had no role in the design of the study; in the collection, analyses, or interpretation of data; in the writing of the manuscript, or in the decision to publish the results.

\section{References}

1. Haynes, E.N.; Heckel, P.; Ryan, P.; Roda, S.; Leung, Y.K.; Sebastian, K.; Succop, P. Environmental manganese exposure in residents living near a ferromanganese refinery in Southeast Ohio: A pilot study. Neurotoxicology 2010, 31, 468-474. [CrossRef] [PubMed]

2. Lucchini, R.G.; Albini, E.; Benedetti, L.; Borghesi, S.; Coccaglio, R.; Malara, E.C.; Parrinello, G.; Garattini, S.; Resola, S.; Alessio, L. High prevalence of Parkinsonian disorders associated to manganese exposure in the vicinities of ferroalloy industries. Am. J. Ind. Med. 2007, 50, 788-800. [CrossRef] [PubMed]

3. Lucchini, R.G.; Guazzetti, S.; Zoni, S.; Donna, F.; Peter, S.; Zacco, A.; Salmistraro, M.; Bontempi, E.; Zimmerman, N.J.; Smith, D.R. Tremor, olfactory and motor changes in Italian adolescents exposed to historical ferro-manganese emission. Neurotoxicology 2012, 33, 687-696. [CrossRef]

4. Lucas, E.L.; Bertrand, P.; Guazzetti, S.; Donna, F.; Peli, M.; Jursa, T.P.; Lucchini, R.; Smith, D.R. Impact of ferromanganese alloy plants on household dust manganese levels: Implications for childhood exposure. Environ. Res. 2015, 138, 279-290. [CrossRef] [PubMed]

5. $\quad$ Rodrigues, J.L.; Araújo, C.F.; Dos Santos, N.R.; Bandeira, M.J.; Anjos, A.L.S.; Carvalho, C.F.; Lima, C.S.; Abreu, J.N.S.; Mergler, D.; Menezes-Filho, J.A. Airborne manganese exposure and neurobehavior in school-aged children living near a ferro-manganese alloy plant. Environ. Res. 2018, 167, 66-77. [CrossRef] 
6. Commission, E. Critical Raw Materials Resilience: Charting a Path towards Greater Security and Sustainability. Available online: https: / / ec.europa.eu/docsroom/documents/42849 (accessed on 1 November 2021).

7. Malala, O.N.; Adachi, T. Japan's critical metals in the medium term: A quasi-dynamic approach incorporating probability. Miner. Econ. 2021, 34, 1-15. [CrossRef]

8. Zhang, W.; Cheng, C.Y. Manganese metallurgy review. Part I: Leaching of ores/secondary materials and recovery of electrolytic/chemical manganese dioxide. Hydrometallurgy 2007, 89, 137-159. [CrossRef]

9. Institut Ruđer Bošković. Elaborat Stanja Okoliša-Plaža "Crnica"; Institut Ruđer Bošković: Zagreb, Croatia, 2011. Available online: https://www.sibenik.hr/upload/dokumenti/2011/Elaborat\%20stanja\%20okoli\%C5\%A1a\%20na\%20podru\%C4\%8 Dju\%20budu\%C4\%87e\%20pla\%C5\%BEe\%20na\%20podru\%C4\%8Dju\%20biv\%C5\%A1e\%20Tvornice\%20elektroda\%20i\%20 ferolegura \%20u\%20\%C5\%A0ibeniku\%20(TEF).pdf (accessed on 1 November 2021).

10. Legović, T.; Gržetić, Z.; Smirčić, A. Effects of wind on a stratified estuary. Mar. Chem. 1991, 32, 153-161. [CrossRef]

11. Pavilonis, B.T.; Lioy, P.J.; Guazzetti, S.; Bostick, B.C.; Donna, F.; Peli, M.; Zimmerman, N.J.; Bertrand, P.; Lucas, E.; Smith, D.R.; et al. Manganese concentrations in soil and settled dust in an area with historic ferroalloy production. J. Expo. Sci. Environ. Epidemiol. 2015, 25, 443-450. [CrossRef]

12. Cheng, Z.; Luo, L.; Wang, S.; Wang, Y.; Sharma, S.; Shimadera, H.; Wang, X.; Bressi, M.; de Miranda, R.M.; Jiang, J.; et al. Status and characteristics of ambient PM2.5 pollution in global megacities. Environ. Int. 2016, 89-90, 212-221. [CrossRef]

13. Selinus, O.; Alloway, B.J. Essentials of Medical Geology: Impacts of the Natural Environment on Public Health; Elsevier: Amsterdam, The Netherlands, 2005.

14. Kero, I.T.; Eidem, P.A.; Ma, Y.; Indresand, H.; Aarhaug, T.A.; Grådahl, S. Airborne Emissions from Mn Ferroalloy Production. JOM 2019, 71, 349-365. [CrossRef]

15. TEF History of Electrodes and Ferroalloy Plant (Povijest TEF-a). Available online: http://www.tef.hr/stranica/5/povijest-tef-astup-sibenskog-industrijskog-razvoja-u-20-stoljecu.html (accessed on 14 June 2021).

16. Mamužić, P. Osnovna Geološka Karta SFRJ 1:100.000, List Šibenik K33-8; Zagreb (1962-1965); Institut za Geološka Istraživanja: Zagreb, Croatia; Savezni Geološki Institut: Beograd, Serbia, 1971.

17. Marinčić, S.; Magaš, N.; Borović, I. Osnovna Geološka Karta SFRJ 1:100.000, List Primošten K33-20; Zagreb, (1968-1969); Institut za Geološka Istraživanja: Zagreb, Croatia, 1971.

18. Vodovod i Odvodnja Šibenik d.o.o. Available online: http:/ / www.vodovodsib.hr/ (accessed on 7 June 2021).

19. Cukrov, N. Krka River Estuary, Trap for Radionuclides; University of Zagreb, Faculty of Science: Zagreb, Croatia, 2006.

20. Cukrov, N.; Surić, M.; Fuček, L.; Ćosović, V.; Korbar, T.; Juračić, M. Geologija estuarija rijeke Krke (Geology of Krka River estuary). In Proceedings of the 4th Hrvatski Geološki Kongres (4th Croatian Geological Congress)—Šibenik 2010, Hrvatski Geološki Institut: Zagreb, Croatia; pp. 143-148. Available online: https://bib.irb.hr/datoteka/493808.2010_vodic_ekskurzije_B1_Cukrov_ et_al.pdf(accessed on 1 November 2021).

21. Cukrov, N. Metal Dynamics in the Sediments of the Krka River Estuary. Ph.D. Thesis, University of Zagreb, Faculty of Science, Zagreb, Croatia, 2020.

22. Legović, T.; Petricioli, D.; Žutić, V. Hypoxia in a pristine stratified estuary (Krka, Adriatic Sea). Mar. Chem. 1991, 32, 347-359. [CrossRef]

23. Bilinski, H.; Kozar, S.; Plavšić, M.; Kwokal, Ž.; Branica, M. Trace metal adsorption on inorganic solid phases under estuarine conditions. Mar. Chem. 1991, 32, 225-233. [CrossRef]

24. Elbaz-Poulichet, F.; Ming Guan, D.; Martin, J.-M. Trace metal behaviour in a highly stratified Mediterranean estuary: The Krka (Yugoslavia). Mar. Chem. 1991, 32, 211-224. [CrossRef]

25. Folk, R.L. The distinction between grain size and mineral composition in sedimentary rock nomenclature. J. Geol. 1954, 62, 344-359. [CrossRef]

26. Wentworth, C.K. A scale of grade and class terms for clastic sediments. J. Geol. 1922, 30, 377-392. [CrossRef]

27. Blott, S.J.; Pye, K. Gradistat: A grain size distribution and statistics package for the analysis of unconsolidated sediments. Earth Surf. Process. Landf. 2001, 26, 1237-1248. [CrossRef]

28. Commeau, J.A.; Poppe, L.J.; Commea, R.F. Separation and Identification of the Silt-Sized Heavy-Mineral Fraction in Sediments; US Government Printing Office: Washington, DC, USA, 1992; Volume 1071. [CrossRef]

29. Austrian Standards Institute. Chemische Bodenuntersuchungen—Bestimmung von Carbonat; Normungsinstitut, O., Ed.; Austrian Standards Institute: Wien, Austria, 2006; pp. 1-8.

30. Kostanjšek, I. Karakterizacija Sedimentnog Okoliša i Plastičnog Otpada Morskog Sedimenta i Plaže u Uvali Stupica Mala (Otok Žirje). Master's Thesis, University of Zagreb, Faculty of Science, Zagreb, Croatia, 2021.

31. Fernández Alborés, A.; Pérez Cid, B.; Fernández Gómez, E.; Falqué López, E. Comparison between sequential extraction procedures and single extractions for metal partitioning in sewage sludge samples. Analyst 2000, 125, 1353-1357. [CrossRef]

32. Hernández-Moreno, J.M.; Rodríguez-González, J.I.; Espino-Mesa, M. Evaluation of the BCR sequential extraction for trace elements in European reference volcanic soils. Eur. J. Soil Sci. 2007, 58, 419-430. [CrossRef]

33. Rauret, G.; López-Sánchez, J.F.; Sahuquillo, A.; Rubio, R.; Davidson, C.; Ure, A.; Quevauviller, P. Improvement of the BCR three step sequential extraction procedure prior to the certification of new sediment and soil reference materials. J. Environ. Monit. 1999, 1, 57-61. [CrossRef] 
34. Pueyo, M.; Mateu, J.; Rigol, A.; Vidal, M.; López-Sánchez, J.F.; Rauret, G. Use of the modified BCR three-step sequential extraction procedure for the study of trace element dynamics in contaminated soils. Environ. Pollut. 2008, 152, 330-341. [CrossRef] [PubMed]

35. Fiket, Z.; Mikac, N.; Kniewald, G. Mass Fractions of Forty-Six Major and Trace Elements, Including Rare Earth Elements, in Sediment and Soil Reference Materials Used in Environmental Studies. Geostand. Geoanalytical Res. 2016, 14, 123-135. [CrossRef]

36. Trisnawati, I.; Prameswara, G.; Mulyono, P.; Prasetya, A.; Bayu Murti Petrus', H.T. Sulfuric Acid Leaching of Heavy Rare Earth Elements (HREEs) from Indonesian Zircon Tailing. Int. J. Technol. 2020, 11, 804-816. [CrossRef]

37. Tessier, A.; Campbell, P.G.C.; Bisson, M. Sequential extraction procedure for the speciation of particulate trace metals. Anal. Chem. 1979, 51, 844-851. [CrossRef]

38. Croatian Geological Survey. Tumač Geološke Karte Republike Hrvatske 1:300.000; Velić, I., Vlahović, I., Eds.; Croatian Geological Survey: Zagreb, Croatia, 2009.

39. Bilinski, H.; Kwokal, Ž.; Branica, M. Formation of some manganese minerals from ferromanganses factory waste disposed in the Krka River estuary. Wat. Res. 1996, 30, 495-500. [CrossRef]

40. Dubinin, A.V. Geochemistry of rare earth elements in the ocean. Lithol. Miner. Resour. 2004, 39, 289-307. [CrossRef]

41. European Union. Directive 2000/60/EC of the European Parliament and of the Council of 23 October 2000 Establishing a Framework for Community Action in the Field of Water Policy. Available online: https://eur-lex.europa.eu/legal-content/EN/ TXT/HTML/?uri=CELEX:32000L0060\&from=EN (accessed on 1 November 2021).

42. European Union. Directive 2010/75/EU of the European Parliament and of the Council of 24 November 2010 on Industrial Emissions (Integrated Pollution Prevention and Control). Available online: https:/ / eur-lex.europa.eu/LexUriServ/LexUriServ. do?uri=OJ:L:2010:334:0017:0119:en:PDF (accessed on 1 November 2021).

43. Australian Government Initiative. Toxicant Default Guideline Values for Sediment Quality. Available online: https://www. waterquality.gov.au/anz-guidelines/guideline-values/default/sediment-quality-toxicants (accessed on 1 November 2021).

44. Bakke, T.; Källqvist, T.; Ruus, A.; Breedveld, G.D.; Hylland, K. Development of sediment quality criteria in Norway. J. Soils Sediments 2010, 10, 172-178. [CrossRef]

45. Pejman, A.; Nabi Bidhendi, G.; Ardestani, M.; Saeedi, M.; Baghvand, A. A new index for assessing heavy metals contamination in sediments: A case study. Ecol. Indic. 2015, 58, 365-373. [CrossRef]

46. Cukrov, N.; Cmuk, P.; Mlakar, M.; Omanović, D. Spatial distribution of trace metals in the Krka River, Croatia: An example of the self-purification. Chemosphere 2008, 72, 1559-1566. [CrossRef] [PubMed]

47. Hernroth, B.; Tassidis, H.; Baden, S.P. Immunosuppression of aquatic organisms exposed to elevated levels of manganese: From global to molecular perspective. Dev. Comp. Immunol. 2020, 104, 103536. [CrossRef]

48. European Parliament. I Directive 2008/50/EC of the European Parliament and of the Council of 21 May 2008 on Ambient Air Quality and Cleaner Air for Europe. Available online: https:/ / eur-lex.europa.eu/legal-content/EN/TXT/PDF/?uri=CELEX: 02008L0050-20150918\&from=DE (accessed on 1 November 2021).

49. Croatian Government. Pravilnik o Praćenju Kakvoće Zraka. 2020. Available online: https://narodne-novine.nn.hr/clanci/ sluzbeni/2020_06_72_1410.html (accessed on 1 November 2021).

50. Zhang, X.; Tan, X.; Yi, Y.; Liu, W.; Li, C. Recovery of Manganese Ore Tailings by High-Gradient Magnetic Separation and Hydrometallurgical Method. Jom 2017, 69, 2352-2357. [CrossRef]

51. Rao, G.V.; Mohapatra, B.K.; Tripathy, A.K. Enrichment of the manganese content by wet high intensity magnetic separation from Chikla manganese ore, India. Magn. Electr. Sep. 1998, 9, 69-82. [CrossRef]

52. Falagán, C.; Grail, B.M.; Johnson, D.B. New approaches for extracting and recovering metals from mine tailings. Miner. Eng. 2017, 106, 71-78. [CrossRef]

53. Dushyantha, N.; Batapola, N.; Ilankoon, I.M.S.K.; Rohitha, S.; Premasiri, R.; Abeysinghe, B.; Ratnayake, N.; Dissanayake, K. The story of rare earth elements (REEs): Occurrences, global distribution, genesis, geology, mineralogy and global production. Ore Geol. Rev. 2020, 122, 103521. [CrossRef]

54. McLemore, V.T. Rare Earth elements (REE) deposits in New Mexico: Update. New Mex. Geol. 2015, 37, 59-69.

55. Costis, S.; Mueller, K.K.; Coudert, L.; Neculita, C.M.; Reynier, N.; Blais, J.F. Recovery potential of rare earth elements from mining and industrial residues: A review and cases studies. J. Geochem. Explor. 2021, 221, 106699. [CrossRef]

56. Jadrijević, A.; Bermanec, V.; Oršulić, D.; Gobac Žigovečki, Ž. Silicomanganese slag as aggregate for asphalt and concrete. Građevinar 2011, 63, 441-447.

57. Hernández-Pellón, A.; Fernández-Olmo, I.; Ledoux, F.; Courcot, L.; Courcot, D. Characterization of manganese-bearing particles in the vicinities of a manganese alloy plant. Chemosphere 2017, 175, 411-424. [CrossRef]

58. Kutchko, B.G.; Kim, A.G. Fly ash characterization by SEM-EDS. Fuel 2006, 85, 2537-2544. [CrossRef]

59. Cukrov, N.; Barišić, D.; Juračić, M. Calculated sedimentation rate in the Krka River estuary using vertical distribution of 137Cs. In Proceedings of the Commission Internatinale pour l'Exploration scientifique de la Mer Mediterranee, Istanbul, Turkey, 9-13 April 2007; Volume 38, p. 81.

60. Gennari, R.F.; Garcia, I.; Medina, N.H.; Silveira, M.A.G. Phosphogypsum analysis: Total content and extractable element concentration. In Proceedings of the 2011 International Nuclear Atlantic Conference-INAC 2011, Belo Horizonte, MG, Brazil, 24-28 October 2011. 